\title{
REE Studies using Mineralogy, Petrography and Multitechniques Approach in and around EDC -
}

P.V. Sunder Raju, CSIR-National Geophysical Research Institute, Hyderabad, Telangana - 500007

The assessment of REE (rare earth elements) and rare-metal potential and geochemical characterization, with implications for metallogeny, is currently underway at alkaline syenite complexes in Andhra Pradesh. The alkaline complexes are located to the west and southwest of the Paleoproterozoic Cuddapah basin in the Ananthapur district. Several alkaline plutons \pm nephyline syenite earlier reported by the Geological Survey of India were relooked for REE bearing minerals and their REE contents using the state of art techniques and multi-techniques approach to resolve the complex mineralogy of Rare Earth Elements (REEs), Around Dancherla, Peddavaduguru, Danduvaripalle, Reddypallae, Chintalchervu areas and Pulikonda complex in Chittor district of Andhra Pradesh. The main Dancherla syenite body is oval-shaped and has a total area at the current level of exposure of around $18 \mathrm{~km}^{2}$. A total of 300 samples were subjected to further geochemical studies and to understand the potential of REE mineralization. The REE mineral phases present as clusters and single entity individual grains viz., apatites, zircon, sphene, titanite and opaques. The SEM studies at higher magnification 10000x reveal clearly REE phases of the mineral allanite $\mathrm{La}, \mathrm{Ce}, \mathrm{Y}(\mathrm{Ce}, \mathrm{Ca}, \mathrm{Y})_{2}$ $(\mathrm{Al}, \mathrm{Fe})_{3}\left(\mathrm{SiO}_{4}\right)_{3}(\mathrm{OH})$ belonging to epidote group with inclusions of bright circular-semi-circular or sub-rounded grains of U-Th (patches) by energy dispersive spectra (EDS). Some representative samples were also studied taking the results obtained from whole rock geochemistry obtained from ICPMS, followed by REE contents by Energy Dispersive X Ray fluorescence (EDXRF), Individual mineral analysis using EPMA-EDS, SEM-EDS and subjected to XRD studies. The major element data confirm syenite chemistry as silica under saturated $\mathrm{SiO}_{2}$ contents of $\sim 40-50 \%$ with $\mathrm{Al}_{2} \mathrm{O}_{3} \sim 10-15 \%$ and $<10 \% \mathrm{FeO}$ (t) respectively and with enriched $\mathrm{Zr}(260 \mathrm{ppm})$ and appreciable amounts of $20 \mathrm{ppm} \mathrm{Nb}, \mathrm{Ta}, \mathrm{Y}$ and Hf respectively. The total $(\Sigma \mathrm{REE})$ is $>2.01 \%, \Sigma$ LREE $(2 \%)$ and $\Sigma$ HREE $(0.1 \%)$. The size of the Peddavaduguru (PVD) syenite bodies range from $2 \mathrm{~km}$ X $100 \mathrm{~m}$ between latitude $77^{\circ} 39^{\prime} 30^{\prime \prime}-77^{\circ} 39^{\prime} 34^{\prime \prime}$ and Long $15^{\circ} 00^{\prime} 38^{\prime \prime}-15^{\circ} 08^{\prime} 15^{\prime \prime}$. The PVD is dyke like body cross cutting with strike $\mathrm{N} 20^{\circ} \mathrm{E}-\mathrm{S} 30^{\circ} \mathrm{W}$ to $\mathrm{N} 35^{\circ} \mathrm{E}-\mathrm{S} 40^{\circ} \mathrm{W}$. The REE mineral phases include apatites, zircon, sphene, titanite, opaques, allanite and fluorite. The major element data confirm with silica understaurated $\mathrm{SiO}_{2}$ (wt\%) contents of $\sim 59.3 \%, \mathrm{Al}_{2} \mathrm{O}_{3} \sim 15 \%$ and $<10 \% \mathrm{FeO}$ (t) and $\mathrm{K}_{2} \mathrm{O}+\mathrm{Al}_{2} \mathrm{O}_{3} \sim 5 \%$ respectively and with enriched $\mathrm{Zr}>7 \%$ and appreciable amounts of $200 \mathrm{ppm} \mathrm{Nb}, \mathrm{Ta}, \mathrm{Y} \sim 600 \mathrm{ppm}$ and $\mathrm{Hf} \sim 320$ ppm respectively. The total $\Sigma$ REE is $>2.01 \%, \Sigma L R E E(2 \%)$ and HREE $850 \mathrm{ppm}$. The rock/chondrite normalized REE - REE(n) pattern show enriched LREE with positive europium anomaly and flat HREE. The syenite body in Reddypallae (RDP) is small plug like circular trending in N-S direction with $100 \times 100 \mathrm{~m}$ occurring at Lat. $78^{\circ} 00^{\prime} 54^{\prime \prime}-78^{\circ} 00^{\prime} 58^{\prime \prime}$ and Long. $14^{\circ} 12^{\prime} 03^{\prime \prime}-14^{\circ} 12^{\prime} 04^{\prime \prime}$. Reddypallae syenite is a small oval shaped body emplaced into AFGS suite and emplaced along western sheared contact zone of the Kadiri schist belt. The major element chemistry studied for 200 samples (average) show $\mathrm{SiO}_{2} 63.5 \%, \mathrm{Al}_{2} \mathrm{O}_{3} 16$ wt $\%$ and $\mathrm{K}_{2} \mathrm{O}+\mathrm{Na}_{2} \mathrm{O}>1 \%$. The total $\Sigma \mathrm{REE}$ is $5765 \mathrm{ppm}, \Sigma$ LREE 4500) and $\Sigma$ HREE $1265 \mathrm{ppm}$. The syenite body in Danduvaripalle (DNP) is oval shaped small plug like trending in NNWSSW direction with $500 \mathrm{x} 1 \mathrm{~km}$ occurring at Lat $77^{\circ} 41^{\prime} 36^{\prime \prime}-77^{\circ} 42^{\prime} 08^{\prime \prime}$ and Long $14^{\circ} 38^{\prime} 15^{\prime \prime}-14^{\circ} 38^{\prime} 20^{\prime \prime}$. The major element chemistry studied for 200 samples (average) show $\mathrm{SiO}_{2} 55 \%, \mathrm{Al}_{2} \mathrm{O}_{3} 12$ wt \% and $\mathrm{K}_{2} \mathrm{O}+\mathrm{Na}_{2} \mathrm{O}>5 \%$. The total $\Sigma \mathrm{REE}$ is $2700 \mathrm{ppm}, \Sigma \mathrm{LREE} 2400$ and ¿HREE 220 ppm.

\section{Mineralogy of REE Mineral Phases}

The major REE mineral phases identified were allanite, ceriate, thorite, columbite, tantalite, apatite, zircon, monazite, pyrochlore euxenite, fluorite, etc... The metamict zircon of varying shapes (hexagonal, amebedoial, rounded, sub-rounded and unzoned zircons were observed from Reddypallae and Peddavadaguru.The columbitetantalite are rounded to sub-rounded grains. The monazite grains show high order pleochroism colours with radial cracks within the grains suggestive of the presence of radioactive elements breaking to daughter and some grains show perfect oscillatory zoning without any perfect grain shape and sizes, they also present as discrete grains and at grain boundaries along the silicate phases.
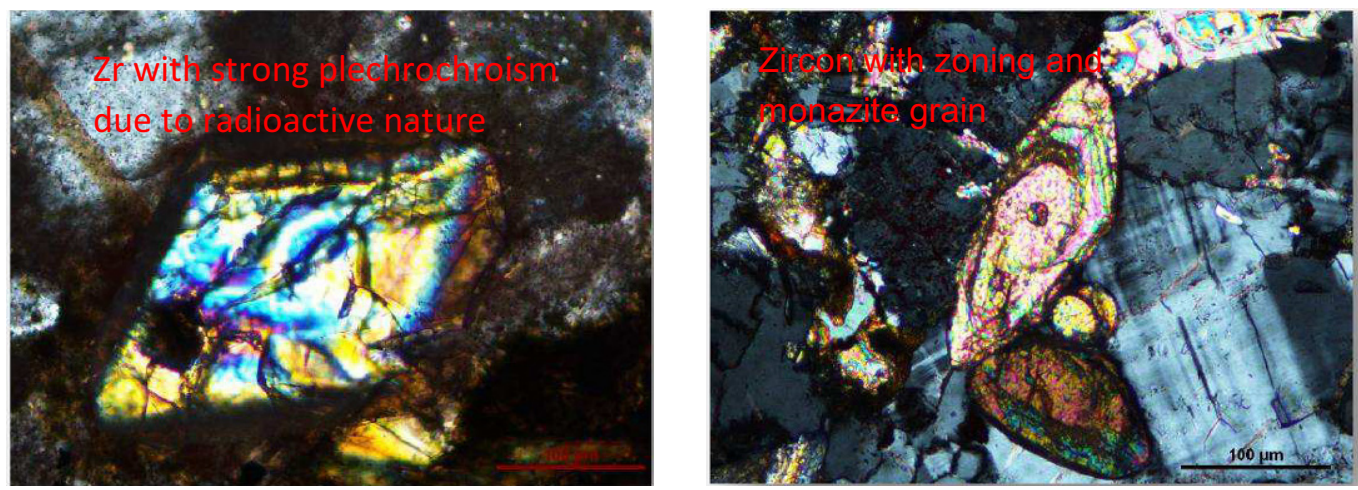

(Summary of the Monthly Scientific Lecture of the Geological Society of India delivered on 29 November 2017) 